\title{
FAZLUR RAHMAN DAN METODE IJTIHADNYA: Telaah Sekitar Pembaruan Hukum Islam
}

\author{
Husein Alyafie \\ STAIN Datokarama Palu, Jl. Diponegoro 23 Palu \\ e-mail: huseinyalyafie@gmail.com
}

\begin{abstract}
In his monumental work, Islamic Methodology in History, Fazlur Rahman proposed two causes of failure of using ijtihâd as a method in interpreting Islamic law among classical Islamic law scholars. Firstly, there is an unharmonious relationship between "sunnah-ijma'-ijtihâd; secondly, there is a burden of majority doctrine theology towards the law. Both causalities are related each other. Fazlur Rahman tried to show the unharmonious between "sunnah-ijma'-ijtihâd" as stated in usûl fiqh. In those unharmonious relationship, ijtihâd is defeated by ijma'. In fact, ijtihâd is regarded as a means to direct and to form ijma'. Due to the ineffective position of ijtihâd, it is not possible to form new ijma'.

كان فضل الرحمن يقول فى أحد مصنفاته البارز Islamic Methodology in بistory

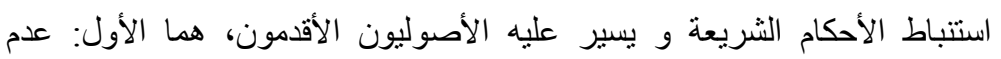

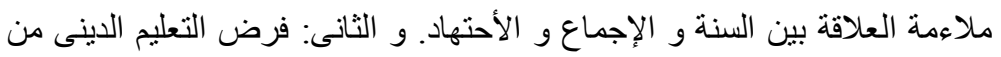

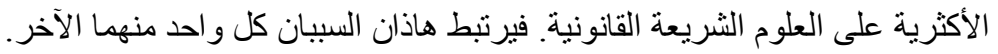

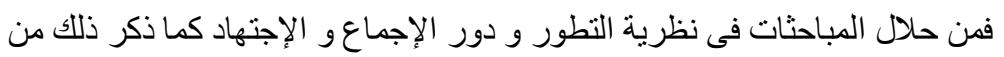

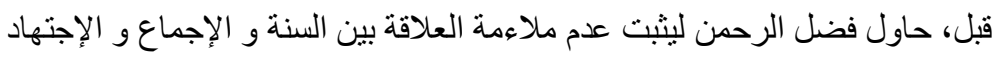

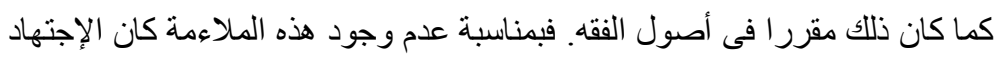

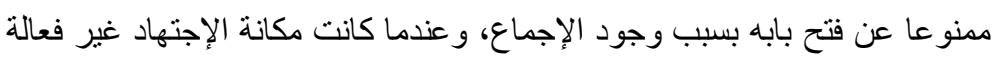
أمام الإجماع كان تلقائيا أن لا يظهر الأجماع من جديد، فلبس هناك إجماع إنداع جديد.
\end{abstract}

Kata Kunci: Fazlur Rahman, metode ijtihad, pembaruan hukum Islam, sunah, ijmak 


\section{PENDAHULUAN}

Terlepas dari setuju atau tidak terhadap gerakan pembaruan Islam, secara faktual corak Islam yang kini berkembang telah mengalami berbagai perubahan, modefikasi, deviasi, dan reinterpretasi dari keislaman yang berkembang pada masa rasul dan pada masamasa para sahabat. Di Indonesia khususnya, selama tiga dasa warsa terakhir, semangat, arah, dan corak pemikiran Islam memiliki "pembaruan pemikiran" yang mengesankan, malah ada pula yang menilai menggamangkan.

Perkembangan ini pada dasarnya berkaitan dengan berbagai aspek ajaran Islam yang selama ini dipandang telah mapan dan terbakukan, khususnya di bidang kajian fikih atau hukum Islam. Keterlibatan ilmu-ilmu sosial yang bersifat empiris dalam menerjemahkan dan menganalisis pesan-pesan Islam dari sumber ajaran pokoknya (Alquran dan sunah), merupakan salah satu faktor signifikan yang melahirkan pembaru-pembaru kontemporer dalam berbagai bidang kajian.

Untuk memahami dan mengembangkan ajaran Islam, sangat diperlukan suatu metodologi (Muhadjir, 1998:9-10) yang diharapkan mampu memberikan interpretasi applicable terhadap sumber ajaran pokok Islam dalam realitas kehidupan umat. Metode yang dimaksud adalah "ijtihad" yang oleh Iqbal dipandang sebagai "the principle of the movement" dalam gerakan pemikiran Islam (Iqbal, 1989:117).

Pada tataran metodologis, hukum Islam dapat dipahami sebagi hukum yang bersumber dari Alquran dan sunah melalui proses penalaran atau ijtihad. Ruang gerak metodologi antara wahyu sebagai sumber hukum yang memuat petunjuk-petunjuk global dan kedudukan ijtihad sebagai fungsi pengembangan memungkinkan hukum Islam memiliki sifat elastis dan akomodatif. Menurut Anderson (1992:42), karakteristik hukum Islam yang bersendikan wahyu dan bersandarkan akal, merupakan ciri khas yang membedakan hukum Islam dari sistem hukum lainnya.

Jika hukum Islam dipandang sebagai suatu sistem pengetahuan, maka yang dimaksudkan metodologi hukum Islam adalah pembahasan konsep-konsep dasar hukum Islam, Alquran dan ijmak, dan 
bagaimanakah hukum Islam tersebut dikaji dan diformulasikan. Dengan pengertian tersebut, metodologi hukum Islam tidak berbeda dengan pengertian usul fikih yang menurut para ahlinya diartikan sebagai sesuatu yang di atasnya dibangun hukum Islam, atau dalildalil yang di atasnya dibangun hukum Islam (Abû Zahra, t.th.:7).

Menurt John L. Esposito, jika para pembaru hendak mengembangkan hukum Islam secara komprehensif dan konsisten sesuai dengan kebutuhan yang mendesak yang dihadapi dunia Islam dewasa ini, adalah keharusan bagi para pembaru untuk merumuskan kembali metodologi hukum Islam yang sistematis dan berpangkal pada dasar-dasar Islam yang kokoh (Esposito, 1982:101-102).

Kehadiran Fazlur Rahman-selanjutnya disebut Rahman-dalam peta pemikiran Islam, agaknya menjadi salah satu jawaban atas apa yang diharapkan oleh Esposito di atas. Rahman dalam berbagai penelitiannya, menekankan aspek metodologi pemikiran Islam di mana hukum merupakan aspek dominan dalam pemikiran metodologinya. Ide dan pemikirannya itu terangkum dalam beberapa bukunya seperti Islamic Methodology in History; Islam; Islam and Modernity; Transformation of in Intellectual Tradition; Major Themes of the Qur'an. Dalam beberapa kajian historis, Rahman berusaha menemukan akar-akar penyebab terjadinya kemacetan intelektualisme Islam secara umum, dan akar-akar kemacetan pemikiran hukum Islam secara khusus. Sebagai terapinya, ia merumuskan konsep-konsep tentang dasar-dasar metodologi hukum Islam, yaitu Alquran, sunah, ijtihad dan ijmak, sekaligus ia merumuskannya dalam konsep-konsep metodis.

Bertolak dari latar belakang tersebut di atas, tulisan akan membahas profil Rahman sebagai tokoh pembaru kontemporer dengan pokok permasalahan "Bagaimana metode ijtihad Rahman terhadap pembaruan hukum Islam". Selanjutnya, pokok permasalahan tersebut dijabarkan dalam sub-sub masalah, yaitu (1) sejauh mana kapasitas dan otoritas Rahman sebagai tokoh pembaru?; dan (2) bagaimana ia merancang dan mengaplikasikan metodologi ijtihadnya?

Rumusan masalah tersebut di atas, secara implisit, tergambar dalam lingkup pembahasan dalam tulisan ini. 


\section{MENGENAL FAZLUR RAHMAN, KARYA DAN KETOKOHANNYA}

\section{Latar Belakang Pendidikan dan Kepribadiannya}

Fazlur Rahman lahir di Pakistan pada tahun 1919, kemudian tumbuh dan berkembang dalam latar belakang pendidikan tradisional hingga usia 39 tahun. Berasal dari keluarga yang bermazhab Hanafi, sebuah mazhab sunni yang lebih bercorak rasional daripada mazhab sunni lainnya (Mas'udi, 1997:15).

Pendidikan formalnya dimulai dari Madrasah. Selain itu, ia juga menerima pelajaran dari orang tuanya, seorang ulama dari Deobond. Setelah menamatkan sekolah menengah di madrasah, ia kemudian melanjutkan studinya di Departemen Ketimuran Universitas Punjab dan berhasil menyelesaikan pendidikan akademisnya di Universitas tersebut dengan meraih gelar Master dalam sastra Arab.

Meskipun Rahman terdidik dalam lingkungan tradisional, sikap kritis mengantar jati dirinya sebagai seorang pemikir yang berbeda dengan kebanyakan alumni madrasah. Sikap kritis yang menggambarkan ketidakpuasannya terhadap sistem pendidikan tradisional, terlihat dengan keputusannya melanjutkan studi ke Barat di Universitas Oxford Inggeris. Keputusan tersebut merupakan awal sikap kontroversinya yang mendapat kecaman keras dari kalangan ulama-ulama Pakistan kala itu yang memandang negatif setiap kecenderungan ke Barat, sekalipun sikap tersebut ditempuh demi kebaikan dan kemajuan umat Islam (Mas'udi, 1997:15).

Rupanya Rahman senasib dengan Sayyid Ahmad Khan, yang jauh sebelum Rahman, pernah menerima kecaman serupa lantaran sikapnya yang pro terhadap politik Inggeris di India, dan lantaran pemikirannya yang rasional ia dituduh oleh para ulama sebagai seorang kafir (Nasution, 1992:168).

Pada tahun 1950, Rahman menyelesaikan studi doktornya di Oxford University dengan disertasi tentang Ibnu Sina. Sementara itu, ia juga sempat merampungkan penerjemahan karya Ibnu Sina, yaitu kitab Al-Najât yang merupakan ikhtisar kitab Al-Shifâ, karya Ibnu Sina yang terbesar. Rahman menguasai banyak bahasa, paling tidak ia menguasai bahasa Latin, Yunani, Inggeris, Prancis, Jerman, Turki, Persia, Urdu, dan Arab (Amal, 1989:81). Ia mengajar beberapa saat di 
Burham University, Inggeris, kemudian menjabat sebagai Associate Professor of Philosophy dalam bidang Islamic Studies di McGill University, Kanada.

Sekembalinya ke tanah airnya, Pakistan, pada tahun 1962, ia diangat sebagai Direktur pada Institute of Islamic Research. Belakangan, ia juga diangkat sebagai anggota Advisory Council of Islamic Ideology oleh Pemerintah Pakistan pada tahun 1964. Lembaga tersebut bertujuan untuk menafsirkan Islam dalam term-term rasional dan ilmiah dalam rangka menjawab tantangan kebutuhan-kebutuhan masyarakat modern yang progresif. Sedangkan Dewan Penasihat Ideologi Islam bertugs meninjau seluruh hukum, baik yang sudah maupun yang belum ditetapkan, dengan tujuan menyelaraskannya dengan Alquran dan Sunah. Kedua lembaga ini memiliki hubungan kerjasama yang erat, karena Dewan Penasihat bisa meminta lembaga riset untuk mengumpulkan bahan-bahan dan mengajukan saran mengenai rancangan undang-undang (Amal, 1993:13-14).

Karena tugas yang diemban oleh kedua lembaga inilah Rahman intens dalam usaha-usaha menafsirkan kembali Islam untuk menjawab tantangan masa itu. Tentu saja gagasan-gagasan liberal Rahman, yang mempresentasikan kaum modernis, selalu mendapat serangan dari kalangan ulama tradisionalis dan fundamentalis di Pakistan. Ideidenya di seputar riba dan bunga bank, sunah dan hadis, zakat, proses turunnya wahyu Alquran, fatwa mengenai kehalalan binatang sembelihan secara mekanis dan lain-lain, telah meledakkan kontroversi-kontroversi berskala nasional yang berkepanjangan. Bahkan pernyataan Rahman dalam karya magnum opus-nya, Islam bahwa Alquran itu secara keseluruhan adalah kalam Allah-dalam pengertian biasa- juga seluruhnya adalah perkataan Muhammad, telah menghebohkan media massa selama kurang lebih setahun. Banyak media yang menyudutkannya. Al-Bayyiât, media kaum fundamentalis, misalnya, menetapkan Rahman sebagai "munkir al-Qur'ân". Puncak kontroversi ini adalah demonstrasi massa dan aksi mogok total, yang menyatakan protes terhadap buku tersebut.

Akhirnya Rahman pun mengundurkan diri dari jabatan Direktur Lembaga Riset Islam pada September 1968, menyusul jabatannya selaku anggota Dewan Penasihat Ideologi Islam turut dilepaskannya 
pada tahun 1969. Akhirnya, Rahman memutuskan hijrah ke Chicago untuk menjabat sebagai Guru Besar dalam kajian Islam dalam segala aspeknya pada Department of Near Eastern Languages and Civilization, University of Chicago. Bagi Rahman, tampaknya tanah airnya belum siap menyediakan lingkugan kebebasan intelektual yang betanggung jawab. Pengabdiannya sebagai Profesor pada Universitas Chicago berawal sejak 1970 (Rahman, 1993:3).

\section{Sekilas Karya-karya Ilmiah Rahman}

Sepanjang karier intelektualnya, Rahman telah menghasilkan 5 buku, selain disertasi doktornya, dan tidak kurang dari 50 artikel yang dimuat di beberapa jurnal internasional (Mas'udi, 1973:20).. Beberapa karya monumentalnya dapat dikemukakan :

- Prophecy in Islam: Philosophy and Orthodoxy. Penulisannya dilatarbelakangi oleh kenyataan bahwa sarjana-sarjana Islam modern kurang menaruh minat dan perhatian terhadap masalah doktrin kenabian. Karya ini pada dasarnya merupakan "religiofilosofis Islam".

- Islamic Methodology in History. Buku ini bertujuan untuk memperlihatkan evolusi historis keempat prinsip pokok metodologi pemikiran Islam: Alquran, sunah, ijtihad dan ijmak; dan untuk memperlihatkan peranan aktual dari prinsip-prinsip tersebut dalam sejarah perkembangan pemikiran Islam (Rahman, 1969). Buku ini membahas evolusi sunah dan praktik ijtihad secara panjang lebar. Penemuannya dalam penelitian ini adalah dalam perjalanan sejarah telah terjadi pergeseran dari otoritas sunah nabi yang hidup dan akhirnya menjadi hadis (Mas'udi, 1997). Sunah nabi merupakan sunah yang ideal; sunah yang hidup merupakan interpretasi-interpretasi kreatif para sahabat dan tabiin terhadap sunah ideal tersebut; sedangkan hadis merupakan upaya penuturan sunah dalam suatu catatan. Dari temuan-temuan tersebut, Rahman berusaha membangun kembali mekanisme sunah-ijtihad-ijmak (Mas'udi, 1997:6).

- Islamic and Modernity: Transformation of an Intellectual Tradition. Buku ini menyuguhkan perkembangan Islam secara umum, dalam keberadaan Islam sekitar 14 abad. Selain 
mempertegas temuan-temuan dalam dua bukunya terdahulu, buku ini juga dilengkapi dengan keberadaan aspek-aspek pemikiran keislaman yang berkembang pada masa stagnasi dan masa pembaruan. Buku ini lebih dominan mengemukakan kritik historis dan belum merumuskan solusi yang memadai kecuali sedikit harapan dan saran-saran yang belum utuh.

Dari kenyataan perkembangan intelektualnya yang melahirkan karya-karya-seperti sebagian telah disebutkan di atasmenunjukkan bahwa karya ilmiah Rahman tidaklah tumbuh sepotongsepotong, melainkan tumbuh secara utuh. Ketika ia melahirkan kritisme terhadap metodologi yang berlaku, sebenarnya ia telah menyiapkan konsep alternatif metodologis. Dan ketika metodologi alernatif itu dirumuskan, sebenarnya rumusan tersebut telah ditetapkan dalam sejumlah kasus aktual yang terjadi sebelumnya, yaitu di Pakistan. Konsep metodologis dan metodisnya ini dituangkan ke dalam karyanya "Major Themes of the Qur'an" yang pada dasarnya karya ini merupakan "Tafsir Alquran" (Mas'udi,1997:14).

\section{Sosok dan Kualitas Ketokohannya}

Tempat rantau yang dituju ketika meninggalkan tanah kelahirannya adalah Negara Paman Sam (USA). Suatu pilihan lingkungan intelektual yang bebas dan bertanggung jawab yang telah menempa dirinya sebagai tokoh modernis Islam peringkat dunia. Atas ketokohannya itulah, kajian-kajian keislaman yang dipimpinnya di Chicago University sebagai Guru Besar, menjadikan Universitas ini paling popular melebihi pusat-pusat kajian lainnya di Amerika. Tidak heran kalau sejumlah sarjana muslim berdatangan dari berbagai penjuru dunia muslim untuk berguru kepadanya, termasuk Indonesia. Di antara murid-muridnya di Indonesia, dapat disebutkan ialah Syafi'i Ma'arif dan Nurcholish Madjid

Tampak jelas, Rahman banyak terinspirasi oleh tindakantindakan kebijaksanaan Umar b. Khattab yang kreatif dan inovaif. Sepintas lalu tindakan-tindakannya itu seakan-akan merupakan penyimpangan, namun sebenarnya ia menghidupkan ruh Alquran dan sunah (Rahman, 1987:4). 
Dengan demikian, Rahman bukanlah seorang tokoh parsial dalam aspek pemikiran tertentu, tetapi ia hampir-hampir menguasai segala aspek pemikiran Islam dalam posisi yang seimbang, Keseluruhan pemikirannya merupakan wujud kesadarannya akan krisis yang dihadapi dunia Islam dewasa ini yang sebagian besar berakar dari sejarah Islam sendiri, dan sebagian lainnya dari tantangan modernitas. Dengan dorongan penuh tanggung jawab terhadap Islam, umat dan masa depan mereka di tengah-tengah tantangan modernitas dewasa ini, Rahman mengabdikan potensi intelektualnya untuk mengatasi krisis tersebut (Rahman, 1987:31-32).

\section{KRITIK TERHADAP METODOLOGI HUKUM ISLAM KLASIK}

Dalam karya monumentalnya, Islamic Methodology in History, Rahman menyimpulkn adanya dua penyebab kemacetan "ijtihad" sebagai salah satu metode yang dipergunakan untuk mengistinbatkan hukum bagi kalangan ulama usul fikih klasik. Pertama, ketidakserasian hubungan antara sunah-ijtihad-ijmak; kedua adalah pembebanan doktrin teologis mayoritas terhadap pemikiran hukum. Kedua penyebab tersebut saling berkaitan (Mas'udi, 1997:88).

\section{Ketidakserasian Hubungan antara Sunah-Ijmak-Ijtihad}

Menurut teori ilmu usul fikih yang dibuat para ahli hukum Islam abad pertengahan, hukum Islam dibangun di atas empat struktur dasar hukum yang disebut sebagai "sumber-sumber hukum Islam", yaitu Alquran, sunah nabi, ijmak dan ijtihad (kias). Dari urutan tersebut, tampak bahwa Alquran merupakan sumber utama hukum Islam. Oleh karena itu, semenjak awal sejarah Islam, hukum Islam telah dipandang sebagai sumber wahyu ilahi, pedoman utama kehidupan sebagai sumber hukum.

Menurut Rahman, dalam perkembangan teori hukum Islam, Alquran memiliki "identitas khas", tidak sebagaimana tiga sumber lainnya, yang di antara ketiga sumber tersebut terjadi interaksi yang erat (Rahman, 1989:75).

Adalah suatu kenyataan bahwa sunah nabi telah melewati proses yang panjang sebelum dibakukan sebagi riwayat-riwayat hadis. Pada saat itu, yaitu ketika hadis belum dibakukan, para shabat dan tabiin, khususnya mereka yang berprofesi sebagai hakim, ahli hukum, 
teoritisi, politikus. dan lain-lain, berupaya menjabarkan dan menafsirkan sunah nabi demi kepentingan kaum Muslimin saat itu. Hasil pemahaman, penafisiran, dan penjabaran tersebut juga dianggap sebagai "sunah" (Rahman, 1997:2-3) dengan pengertian sebagai praktik yang disepakati bersama atau "sunah yang hidup". Jelas evolusi sunah nabi menjadi "sunah yang hidup" terjadi melalui interaksi "ijtihad", yaitu upaya penjabaran dan penafsiran "sunah nabi" menjadi "sunah yang hidup", yaitu sunah dan teladan nabi, karena itulah mengapa dalam "sunah yang hidup" terdapat banyak pertentangan.

Untuk mendukung eksistensi "sunah yang hidup", Rahman memperlihatkan beberapa bukti sejarah, misalnya, kebiasaan berargumentasi bidang hukum pada saat itu adalah "demikianlah praktik kaum muslimin atau pemimpin muslim", upaya Imam Malik mengumpulkan riwayat-riwayat (bukan hanya riwayat hadis nabi) untuk mempertahankan sunah kaum muslimin Madinah, bahkan oleh Malik, "sunah ahli Madinah" dipandang lebih kuat daripada riwayat "hadis ahad". Perdebatan Imam Syafi'i dengan ahli hukum Madinah yang direkam dalam beberapa kitab karya Imam Syafi'i, sikap beberapa ahli hukum sepeti al-Auzâ'i, Abû Yûsuf, Al-Shaybanî yang sering kali mereka tidak berpegang pada hadis-hadis hukum yang bersumber pada nabi kecuali menafsirkannya secara bebas (Rahman, 1997:39-40).

Gerakan hadis yang dilancarkan oleh Al-Syafi'i (150-204 H/767819 M.) dilatarbelakangi oleh tumbuhnya pemikiran bebas pada saat itu yang dalam beberapa hal menghasilkan keputusan yang bertentangan dengan hadis. Arah yang hendak dicapai oleh gerakan ini adalah "menekan" tumbuhnya praktik-praktik atau "sunah yang hidup" (Mas'udi, 1997:90).

Kesimpulan Rahman dari analisis proses evolusi sunah nabi menjadi "sunah yang hidup" yang kemudian diformalisir menjadi "hadis", adalah bahwa sebagian besar dari "hadis" itu tidak lain merupakan "sunah" hasil ijtihad generasi pertama kaum muslimin. Sunah tersebut berasal dari ide individu, tetapi setelah lama berinteraksi, akhirnya menjadi praktik yang disepakati di kalangan mereka, atau menjadi "ijmak". Dengan kata lain, sunah yang hidup di 
masa awal terebut terlihat sebagai "hadis" dengan disertakan rangkaian perawi (Rahman, 1997:45).

Dengan uraian mengenai evolusi dan peranan ijmak dan ijtihad sebagaimana yang telah dikemukakan, Rahman berusaha menunjukkan ketidakserasian antara "sunah-ijmak-ijtihad" sebagaimana terbakukan dalam usul fikih. Dalam hubungan yang tidak serasi tersebut, jelas ijtihad terdepak oleh ijmak, padahal ijtihad sebenarnya merupakan sarana pengarah dan penuntun terbentuknya ijmak. Dalam posisi ijtihad yang tidak efektif tersebut, secara otomatis tidak mungkin terbentuk ijmak-ijmak baru .

\section{Pembebanan Doktrin Teologis terhadap Pemikiran Hukum}

Menurut Rahman, pembebanan dogma-dogma teologis antara kalangan Mu'tazilah dengan kalangan Ortodoks (Ahlusunah), pada akhirnya didominasi oleh paham ortodoks yang umumnya dianut oleh kalangan ulama usul fikih yang dengan sendirinya menolak faham Mu'tazilah yang sangat mengagungkan 'aql (akal) melebihi dari "wahyu" yang berimplikasi pada pemikiran hukum Islam.

Dalam latar belakang kemapanan situasi sosial masyarakat muslim, maka konsep-konsep usul fikih berfungsi sebagai sarana untuk merumuskan hukum dari dalil-dalil syar'i. Hal ini sebagaimana terlihat dalam pengertian usul fikih yang disampaikan oleh para ahlinya (Al-Amidi, 1968:61). Dalam posisi sebagai metode istimbât $\square$ al-hukm, maka usul fikih memakai dalil-dalil syar'i seara apriori tanpa mempertimbangkan latar belakang sosiologis dalil-dalil tersebut dan tanpa mengaitkan dengan kasus-kasus hukum (al-waq'at) aktual. Maka pada dasarnya konsep-konsep istimbâth al-hukm merupakan proses pemikiran induktif atas dalil-dalil syar'i. Hal ini sangat berbeda dengan konsep tat $\square$ bîq al-hukm (penerapan hukum) yang bercorak pemikiran deduktif, yaitu penerapan dalil-dalil syar'i terhadap kasuskasus terentu. Dalam rentang waktu dan latar belakang situasi dan kondisi yang berbeda, hampir-hampir dapat dipastikan tidak ada dua kasus yang sama persis. Sekedar contoh, kasus riba pada zaman nabi dan kasus bank pada zaman sekarang, merupakan dua kasus yang berbeda, meskipun keduanya sama-sama membungakan uang. Unsurunsur motif, fungsi dan latar belakang sosiologis yang mengitari keduanya sebagai sebuah sistem, menjadikan satu sama lainnya sama 
sekali berbeda. Maka upaya tat $\square$ bîq al-hukm sangat diperlukan adanya kajian analisis dan kritis terhadap kasus dan terhadap dalildalil syar'i. kajian-kajian tersebut jelas memerlukan peranan akal, nalar atau ijtihad yang lebih besar daripada upaya isthinbât al-hukm, dan hasilnya akan lebih bervariatif sebagaimana variatifnya kasuskasus yang dihadapi.

Demikianlah gambaran umum muatan usul fikih serta analisis kemapanan latar belakang sosial yang mengitarinya di masa-masa klasik yang dinilai Rahman bercorak formalistik. Kritik Rahman berlatar belakang situasi dan kondisi masyarakat Islam abad XX yang dalam berbagai aspek kehidupannya telah banyak mengalami perubahan. Perubahan adalah sesuatu yang riil dan manusiawi, sementara isi teks Alquran dan sunah nabi bersifat sebaliknya, yaitu permanen. Membiarkan dua dimensi hukum Islam, yaitu teks dalil dan fenomena hukum (waqi'at) dalam sifat dan konteksnya masingmasing, jelas akan menimbulkan kesenjangan antara hukum dan kenyataan hukum yang dihukumi : istimbât $\square$ al-hukm menghasilkan hukum $X$, sedangkan tat $\square$ bîq al-hukm menghendaki hukum $Y$. Dalam kondisi dikotomis ini, visi alternatif "transformasi hukum Islam", yaitu perubahan hukum Islam pada tataran tat $\square b \hat{\imath} q$ al-hukm dengan tetap mempertahankan rumusan hukum hasil istinbât $\square$, merupakan visi alternatif yang tidak konsekuen. Yang konsekuen adalah "transformasi hukum Islam", yaitu perubahan hukum Islam yang tidak hanya pada tataran tat $\square b \hat{\imath} q$ tetapi juga perubahan pada tataran istinbât $\square$. Untuk mendukung alternatif terakhir ini, diperlukan rekonstruksi metodologi hukum Islam yang mencakup konseptualisasi dasar-dasar hukum Islam dan operasionalisasi konsep-konsep tersebut dalam rumusan metodik. $\mathrm{Ke}$ arah alternatif inilah pemikiran metodologi Rahman (Mas'udi, 1997).

\section{METODOLOGI IJTIHAD FAZLUR RAHMAN}

\section{Ijtihad menurut Rahman}

Selaras dengan konsep-konsep mengenai dasar-dasar hukum Islam, khususnya mengenai Alquran dan Sunah, selanjutnya Rahman membangun konsep ijtihad yang khas, kemudian merumuskan metodiknya yang khas pula. Menurut Rahman, ijtihad merupakan 
suatu usaha yang keseluruhan unsur-unsurnya mengandung muatan "jihad" intelektual. Ia mendefinisikan ijtihad dalam sebuah konsep yang sekaligus mengandung implikasi metodologis, metodis dan fungsional sebagai berikut:

Ijtihad berarti upaya memahami makna suatu teks atau preseden di masa lampau yang mengandung suatu aturan, dan mengubah aturan tersebut dengan cara memperluas atau membatasi atau pun memodefikasinya dengan cara-cara yang lain sedemikian rupa sehingga suatu situasi baru dapat dicakup ke dalamnya (Rahman,1997:8).

Implikasi metodis yang terkandung di dalam definisi tersebut di atas adalah "bahwa kerja ijtihad meliputi: pemahaman teks dan preseden dalam keutuhan konteksnya di masa lampau; pemahaman situasi baru yang sedang terjadi sekarang; dan perubahan aturanaturan hukum yang terkandung di dalam teks atau preseden. Adapun implikasi fungsional dalam definisi tersebut adalah: bahwa konsep metodologis dan perumusan metodis tersebut difungsikan untuk upaya pembaruan hukum Islam" (Mas'udi, 1997:149) dalam upaya menjawab tantangan situasi baru.

\section{Pedekatan yang Digunakan}

Sekaitan dengan metode ijtihadnya, Rahman mengajukan (tiga) pendekatan, yaitu: pertamam pendekatan historis untuk menemukan makna teks; kedua, pendekatan kontekstual untuk menemukan sasaran dan tujuan yang terkandung dalam ungkpan legal spesifik; dan ketiga, pendekatan latar belakang sosiologis untuk menemukan sasaran dan tujuan yan tidak dapat diungkapkan oleh pendekatan kontekstual.

Sasaran atau objek dari ketiga pendekatan metodologis yang dikemukakan Rahman di atas adalah bidang-bidang hukum yang bermuatan sosial, bukan bidang teologi, ibadah dan bukan pula ajaranajaran moral itu sendiri.

Ujung dari keseluruhan ide dan konsep metodologinya, ia rumuskan dalam dua gerakan metodis yang masing-masing terdiri dari serangkaian kerja intelektual yang secara teknis dinamakannya "ijtihad" atau "jihad intelektual". Sebagaimana definisi ijtihad yang mengimplementasikan konsep-konsepnya mengenai dasar-dasar metodologis; tentang Alquran, sunah, maka demikian pula rumusan 
metodis Rahman sehingga terlihat konsistensi dan koherensi pemikiranya: sejak dari ide-ide pendekatan metodologis, konsepkonsep tentang dasar-dasar metodologis; konsep ijtihad; sampai dengan rumusan metodologisnya.

\section{Dua Gerakan Metodik yang Digunakan}

\section{Gerakan Pertama}

Geraan pertama dari dua gerakan metodis, yang terdiri dari dua langkah, pada dasarnya merupakan penjabaran dari tiga pendekatan pemahaman dan penafsiran Alquran, yaitu pendekatan historis, kontekstual, dan sosiologis. Agaknya gerakan pertama ini lebih dikhususkan terhadap ayat-ayat hukum. Rumusan gerakan pertama ini diungkapkan sebagai berikut:

\footnotetext{
Langkah pertama, orang harus memahami arti atau makna suatu pernyataan (ayat) dengan mengkaji stuasi atau problema histories di mana pernyataan Alquran tersebut merupakan jawabannya. Tentu saja sebelum mengkaji ayat-ayat spesifik dalam situasi-situasi spesifiknya, suatu kajian situasi makro dalam batasan-batasan masyarakat, agama, adat-istiadat, lembaga bahkan keseluruhan kehiupan masyarakat di Arabia pada saat Islam datang dan khususnyas di Makkah dan sekitarnya, harus dilakukan terlebih dahulu. Langkah kedua, adalah menggeneralisasikan respon-respon spesifik tersebut dan menyatakannya sebagai ungkapan-ungkapan yang memiliki tujuan moral sosial umum, yang dapat disaring dari ungkapan ayat-ayat spesifik dalam sinar latar belakang sosio-historis dan dalam sinar "rationes leges" ('illat hukm) yang sering digunakan. Benarlah bahwa langkah pertama yaitu memehami makna dari suatu pernyataan spesifik -sudah memperlihatkan ke arah langkah kedua - dan membawa kepadanya. Selama proses ini perhatian harus ditujukan kepada ajaran Alquran sebagai suatu keseluruhan, sehingga setiap arti tertentu yang dipahami, setiap hukum yang dinyatakan, dan setiap tujuan yang dirumuskan akan koheren dengan yang lainnya. Alquran sendiri menda'wakan secara pasti bahwa "ajaran tidak mengandung kontradiksi", melainkan koheren dengan keseluruhan (Rahman, 1979:221).
}

Ide pokok yang terkandung dalam gerakan pertama,s ebagaimana dikutip di atas adalah penerapan metode berpikir induktif :"berpikir dari ayat-ayat spesifik menuju kepada prinsip", atau dengan kata lain adalah "berpikir dari aturan-aturan legal spesifik menuju pada moral sosial yang bersifat umum yang terkandung di dalamnya 
(Rahman, 1979). Terdapat tiga perangkat untuk dapat menyimpulkan prinsip moral-sosial. Pertama adalah prangkat ilat hukum (ratio leges) yang dinyatan dalam Alquran secara eksplisit; kedua, ilat hukm yang dinyatakan secara implisit yang dapat diketahui dengan cara menggeneralisasikan beberapa ungkapan spesifik yang terkait; ketiga adalah perangkat sosio-historis yang bisa berfungsi untuk menguatkan ilat hukum implisit untuk menetapkan arah maksud tujuannya, juga dapat berfungsi untuk membantu mengungkapkan ilat hukum beserta tujuannya yang sama sekali tidak dinyatakan (Rahman, 1979:222).

Mengenai ilat (ratio logis, alasan hukum) dan hikmat (sasaran), pada prinsipnya Rahman sependapat dengan Syaikh Yamani, bahwa kedua kata tersebut mengandung implikasi makna yang berbeda jika dikaitkan dengan aspek ibadah (religious), tetapi jika dikaitkan dengan aspek muamalah (pranata sosial), eduanya memiliki pengrtian yang erat. Namun Rahman tidak sependapat jika dikatakan bahwa dalam aspek ibadah tidak terkandung hikamat dan dalam aspek muamalah tidak terkandung ni;ai religius, atau semata-mata dikatakan sekuler. Hal ini sebagaimna dikatakan oleh mayorits muslim sekularis yang mengidentifikasikan "aspek religius" sebagai hal-hal yang bersifat abadi, tidak dapat diubah karena terkandung hikmah di dalamnya, sedangkan muamalah dipandang sebagai hal-hal yang mutlak, dan bebas mengalami perubahan. Menurut Rahman, di dalam aspek ibadah terdapat hikmah sebagaimana terdapat dalam aspek mamalah. Namun antara keduanya mempunyai kualifikasi (standar) yang berbeda. Standar hikmah dalam aspek muamalah adalah nilai logis, sebaliknya spek-aspek sosial juga mengandung nilai-nilai religius yang bersifat abadi, tida semata-mata bersifat sekuler. Nilai nilai moral-sosial yang terkadang dalam aspek muamalah adalah bersifat religius dan abadi. Bahkan hukum-hukum yang ditarik dari nilai-nilai moral-sosial tersebut sebagai respon terhadap zaman apapun juga brsifat religius, sekalipun ia tidak bersifat abadi (Rahman, 1979:220).

Dengan bahasa lain, aturan (hukum) sosial bisa saja sepanjang tidak bertentangan dengan nilai-nilai dan tujuan moral-sosial. Perubahan hukum yang melanggar nilai-nilai dan tujuan moral-sosial tidak dapat dibenarkan secara Islam. Rahman sendiri tidak pernah 
mempermasalahkan nilai-nilai atau prinsip-prinsip moral-sosial tersebut apakah sebagai ilat ataupun sebagai hikmah.

\section{Gerakan Kedua}

Gerakan kedua merupakan upaya perumusan prinsip-prinsip umum, nilai-nilai dan tujuan-tujuan Alquran yang telah disis tematisasikan melaui gerakan pertama terhadap situasi dan atau kasus aktual sekarang. Rumusan gerakan kedua ini dinyatakan Rahman sebagai berikut:

Gerakan kedua harus dilakukan dari pandangan umum (yaitu yang telah disistematisasikan melalui gerakan pertama) menjadi pandanganpandangan spesifik yang harus dirumuskan dan direalisasikan sekarang ini. Artinya, ajaran-ajaran yang bersifat umum tersebut harus dirumuskan dalam konteks sosio-historis yang konkrik sekarang ini. Sekali lagi kerja ini memerlukan kajian yang cermat atas situasi sekarang dan analisis berbagai unsur komponennya, sehingga kita dapat menilai situasi sekarang yang diperlukan dan menentukan prioritas-prioritas baru untuk bisa mererapkan nilai-nilai Alquran secara baru pula (Rahman, 1987).

Dari kutipan di atas, terlihat bahwa dalam gerakan kedua ini terdapat dua kerja yang saling terkait. Pertama adalah kerja merumuskan prinsip umum Alquran menjadi rumusan-rumusan spesifik, maksudnya yang berkaitan dengan tema-tema khusus, misalnya prinsip ekonomi qurani; prinsip demokrasi qurani; prinsip hak-hak asasi qurani dan lain-lain, di mana rumusan prinsip-prinsip tersebut harus mempertimbangkan konteks sosio-historis yang konkrit, dan bukan rumusan spekulatif yang mengawang-awang, kerja pertama tidak mungkin terlaksana kecuali disertai kerja kedua yaitu pembahasan secara akurat terhadap kehidupan actual yang sedang berkembang dalam segala aspeknya: ekonomi, politik, budaya, dan lain-lain. Kenyataan kehidupan aktual suatu masyarakat atau bangsa memiliki corak-corak tertentu yang bersifat situasional dan kondisional. Selain itu, ia sarat akan perubahan-perubahan. Oleh karena itu, tanpa pencermatan situasi dan kondisi aktual, akan cenderung kepada upaya pemaksaan prinsip-prinsip qurani, sedangkan yang diinginkan Rahman bukanlah seperti itu, melainkan hanyalah "perumusan" prinsip umum Alquran dalam konteks sosio-historis aktual. Bahkan suatu prinsip tidak dapat diterapkan sebelum ia dirumuskan kembali. 
Pada dasarnya rumusan gerakan metodik kedua di atas tidak berbeda dengan metode "tah $\square q \hat{\imath} q$ al-manât" yang diusulkan secara sederhana oleh Al-Amidi (w. $631 \mathrm{H}$ ), yaitu metode untuk mengetahui sekaligus memastikan adanya ilat hukum pada kasus (waqi'ât) yang akan ditetapkan hukum atasnya (Al-Amidi, 1969: 279). Term $b a$ 'da ma'rîfatihâ fi masâ'ilihâ (setelah mengetahui kasus tersebut) merupakan kata kunci yang cukup sederhana dalam metode "tahqî $q$ al-manât $\square$ " yang mengandung implikasi yang luas sebagaimana yang dikonkritkan oleh Rahman dalam rumusan metodik gerakan keduanya. Bahkan Al-Amidi tampak lebih liberal dari pada Rahman karena ia tidak melibatkan unsur "pengontrol" atau "pengendali" dalam metode "tahqîq al-manât $\square$ "-nya. Jadi, pada satu sisi, gerakan metodik kedua Rahman menjabarkan simplisitas metode yang diusulkan oleh AlAmidi, sedangkan pada sisi lainnya, ia membatasi dengan memfungsikan prinsip-prinsip umum qurani sebagai penggerak kecenderungan progresif kondisi aktual sekaligus sebagai pengontrol atasnya.

Dua gerakan tersebut akhirnya menghasilkan rumusan-rumusan spesifik qurani mengenai berbagai aspek kehidupan aktual sekarang ini. Rumusan-rumusan tersebut akan menjadi pertimbangan bagi mujtahid yang bersangkutan dalam menetapkan pendapat-pendapat hukumnya. Keduanya, yaitu rumusan-rumusan spesifik qurani mengenai kehidupan aktual mengenai pendapat-pendapat hukum hasil ijtihad akan mengalami proses interaksi dalam masyarakat. Terlepas dari kenyataan apakah keduanya akan diterima atau ditolak dalam masyarakat, namun secara teoritis keduanya merupakan visi qurani yang dibangun dengan mempertimbangkan situasi dan kondisi aktual masyarakat setempat., yaitu sebuah visi qurani yang realistis. Sampai di sini kerja ijtihad informal telah rampung, sedangkan kristalisasi hasil ijtihad menjadi ijmak dan kebijakan taqnîn merupakan upaya sosialisasi hasil ijtihad, dan bukan ijtihad itu sendiri.

Duan gerakan metodis Rahman yang disebutnya sebagai "ijtihad intelektual", barang pasti akan menghasilkan keputusan-keputusan hukum yang baru jika dibandingkan dengan ketetapan fikih yang telah dahulu dirumuskan oleh fuqaha, atau bahkan akan menghasilkan keputusan-keputusan yang menyimpang sedikit atau banyak dari 
aturan-aturan yang terkandung secara tekstual dalam ayat-ayat hukum. Kemungkinan itu sangat besar, namun tidak meungkin akan menghasilkan keputusan hukum yang menyimpang dari prinsip umum Alquran. Rahman sendiri secara gamblang mendefinisikan ijtihad sebagai "kerja untuk memperbaharui-atau jika menggunakan bahasa yang tegas adalah "mengubah"-aturan-aturan yang terkandung di dalam Alquran atau preseden agar keduanya mampu mencakupi situasi dan kondisi baru dengan memberikan sebuah solusi baru pula.

Selanjutnya Rahman menjelaskan "ijtihad/jihad intelektual" itu tidak sekedar kerja bahasa melalui seperangkat kaidah kebahasaan, tetapi sesungguhnya ia memerlukan keterlibatan perangkat kerja sainssains kesejarahan untuk mengungkapkan tata kehidupan masyarakat Arab pra-Islam dan masyarakat muslim masa nabi sebagai latar belakang sosiologis Alquran dalam segala aspek kehidupan aktual mereka: agama. politik, ekonomi, kebudayaan dan pranata sosial lainnya. Selain itu, juga memerlukan keterlibatan sains-sains sosial modern untuk mengungkapkan situasi dan kondisi kehidupan actual sekarang ini dalam segala aspeknya. Berdasarkan pertimbangan inilah, Rahman menolak ijtihad sebagai hak previlese exlusive kalangan ulama (Rahman, 1989:499) karena kenyataannya para ulama yang mayoritas keluaran sistem pendidikan Islam tradisional seperti pendidikan pesantren dan madrasah yang mengabaikan pemberian peranan filsafat bagi peserta didiknya sebagai sarana berpikir kritis dan tidak pula dibekali sains-sains sosial modern. Karena "minimnya dan kekunoan ilmu-ilmu yang mereka tekuni menghalangi mereka untuk bisa menempati posisi sebagai orang-orang yang mau berpikir jernih", ungkap Rahman (1967:498). kiranya rekonstruksi sistem pendidikan Islam seperti tengah mulai digalakkan sekarang ini diharapkan sebagai penawar krisis intelektual masyarakat Islam.

\section{APLIKASI IJTIHAD FAZLUR RAHMAN}

\section{Zakat}

Dalam kedudukannya sebagai anggota Dewan Penasehat Ideologi Pakistan pada awal 1966, Rahman menyarankan agar pemerintah merasionalisasikan sistem perpajakan dengan menerapkan sistem zakat, membenahi tarifnya dan memperluas cakupannya pada 
sektor investasi kekayaan sehingga mendorong motivasi Islam para pembayar pajak dan meminimalkan pengelakan pembayaran pajak. Saran tersebut didasarkan pada penafsiran terhadap rincian distribusi zakat dalam QS. Al-Taubah (9):60 yang menurutnya mencakup seluruh aspek pembiayaan Negara, meliputi biaya pertahanan, pendidikan, komunikasi dan bahkan biaya pendelegasian diplomatik.

Dengan berdasarkan pada QS. Al-Hasyr (59):7. Rahman menyatakan bahwa ayat tersebut merupakan petunjuk umum yang salah satu realisasi hukumnya adalah perlunya institusi zakat. Akan tetapi para fuqaha sepanjang abad pertengahan-menurut Rahmantidak mempertemukan petunjuk umum Alquran ini dengan institusi zakat. Menurut Rahman, zakat harus mencakup seluruh aktivitas dan kebutuhan dana sebuah Negara moderen (Amal, 1989:97).

Ide Rahman ini mendapat reaksi keras dari masyarakat yang digerakkan oleh para ulama Pakistan hingga menjadi kontroversi yang berskala nasional. Bahkan kelompok moderat sekalipun menyindir dan menganggap Rahman terlalu tergesa-gesa berijtihad ketika masyarakat belum siap menerima sebuah perubahan. Namun, golongan moderat sepakat, dengan catatan agar penerapannya bertahap; pertama, pemerintah mengumpulkan zakat berasarkan kerelaan, setelah itu zakat diubah menjadi zakat formal, kemudian sistem perpajakan dimasukan ke dalam naungan zakat dengan mengubah strukturnya.

\section{Poligami}

Ayat yang berkaitan dengan poligami adalah QS. Al-Nisâ (4):3 dengan konteks ayat yang berkaitan dengan permasalahan gadis-gadis yatim yang telah berusia dewasa. QS. Al-Nisâ (4):2, di mana wali mereka tidak berkenan menyerahkan harta kekayaan anak yatim yang dikuasainya. QS. Al-Nisâ (4):3 memang menganjurkan poligami dengan disertai syarat bahwa para suami mampu berbuat adil, dengan diiringi penekanan "jika engkau kuatir tidak mampu berbuat adil, cukuplah hanya dengan seorang istri". Selanjutnya sebagaimana pada ayat kedua, yang memerintahkan berbuat adil pada anak-anak yatim. QS. Al-Nisâ (4):129 juga menegaskan "kamu sekali-kali tidak akan mampu berbuat adil kepada isteri-isterimu walaupun sesungguhnya 
kamu sangat menghendaki untuk berbuat demikian-(jika engkau tidak mampu berbuat adil sepenuhnya)-maka setidak-tidaknya janganlah kamu cenderung sepenuhnya kepada salah satunya sehingga yang lain terkatung-katung".

Rahman mencoba mendekati nas ini dengan menggali nilai yang terkandung di dalam teks formalnya bedasarkan sosio-historis dan kulturalnya. Rahman tidak sependapat bahwa frasa "berlaku adil" dalam ayat 3 surat Al-Nisâ hanya terbatas pada perlakuan lahiriah. Jika frase tersebut hanya bermakna demikian, niscaya tidak mungkin ada penegasan pada peringatan ayat 129 surat Al-Nisâ. Frase tersebut hanya tepat jika ditafsirkan dalam aspek psikis,cinta kasih. Ia beralasan dengan ayat-ayat yang mengatur poligami sudah menjadi semacam endemic dalam struktur sosial Arab pada masa itu, maka Alquran secara bijaksana menerima status quo tersebut dengan disertai langkah-langkah perbaikan melalui sejumlah rancangan hukum. Tetapi bersamaan dengan itu Alquran juga mengemukakan rancangan moral di mana masyarakat secara gradual dianjurkan menuju ke arah tersebut, yaitu "monogamy".

Dengan memandang izin poligami bersifat temporer dan memandang bahwa maksud yang hendak dituju oleh Alquran yang sebenarnya adalah menegakkan "monogami", akan meneyelamatkan ayat 3 dan ayat 129 surat Al-Nisâ dari pengertian yang kontradiktif. Masalah poligami berkaitan erat dengan konteks keadilan sosial terhadap wanita.

\section{Bunga Bank}

Pada tahun 1966, Pemerintah Pakistan mengajukan rancangan anggaran belanja kepada sidang Majelis Nasional. Rancangan tersebut ditolak karena didasarkan pada bunga bank yang dipandang oleh para ulama tidak islami. Maka dari itu, pemerintah meminta Rahman agar mengadakan penelitian mengenai bungan bank dan riba. Hasil penelitian Rahman menyimpulkan bahwa sistem ekonomi bisa saja disusun berdasarkan bank yang bebas bunga. Akan tetapi keadaan saat itu tidak memungkinkan bagi konstruksi idealitas tersebut. Selama masyarkat kita (Pakistan belum dibangun berdasarkan pola Islam ...), maka penghapusan bungan bank berarti melangkah menuju bunuh diri 
bagi kesejahteraan ekonomi masyarakat dan bagi sistem finansial Negara serta juga bertentangan dengan spirit dan tujuan Alquran dan sunah jika bunga bank dihapus.

\section{Keluarga Berencana}

Dengan mengutip pandangan Syaltut, Rahman (dalam Donald, 1976:283) membolehkan keluarga berencana. Rahman aktif terlibat dalam penyuluhan keluarga berncana. Dalam seminar di Lahore 1964, ia mengatakan bahwa ide umum yang melatarbelakangi larangan klasik terhadap konsepsi kontrol pendududk adalah agar masyarakat tidak dapat dilemahkan dengan penyusutan jumlah penduduk. Ia juga mengeritik pseudo argumen kalangan tradisionalis dan fundamaentalis yang diangkat dari Alquran dan hadis untuk mendukung gagasan klasik tentang masyarakat. Selanjutnya ia menilai bahwa gagasan klasik tentang masyarakat yang kuat dewasa ini terancam oleh pertumbuhan populasi yang semborono. Menurutnya, gagasan itu dapat diiemplementasikan dengan baik melalui perbaikan kualitas umat Islam yang salah satu solusinya adalah "keluarga berencana".

\section{Penyembelihan Secara Mekanis}

Pada tahun 1967, Rahman dimintai fatwanya oleh Komisaris Tinggi Pakistan di London mengenai upaya pendirian penyembelihan hewan secara mekanis. Ketika membalas surat tersebut, Rahman secara singkat menjawab bahwa tidak ada bahayanya dalam penyembelihan secara mekanis, maksudnya hukum sembelihan mekanis tersebut halal.

Pandangan ini juga menuai kritikan dari masyarakat, termasuk dari kalangan ulama. Ketika kontroversi tersebut memanas dan mulai melebar ke masalah wajib tidaknya penyebutan "basmalah" ketika menyembelih, Rahman melayangkan surat pembelaan diri ke Harian The Pakistan Times, dan dipublikasikan pada tanggal 25 Desember 1967. Dalam suratnya, ia membela diri dengan menunjuk pandangan Mazhab Syafi'i, bahwa dalam situasi ketika tidak ada kecurigaan bahwa penyembelihan binatang akan mendedikasikan penyembelihannya kepada selain Allah, maka penyebutan "basmalah" ketika menyembelih tidak dibutuhkan. Ia menyatakan 
ketidaksetujuannya terhadap pandangan Mazhab Hanafi yang mewajibkan formula tersebut dalam setiap penyembelihan.

\section{PENUTUP}

Dari uraian yang telah dikemukakan dapat dirumuskan beberapa kesimpulan pokok, sekaligus merupakan penegasan jawaban atas permasalahan yang diangkat, sebagai berikut: (1) Rahman sebagai intelektual Islam modern tidak hanya mengembangkan pemikiran hukum Islam, tetapi juga mengenai pemikiran Islam lainnya, namun pemikiran di bidang hukum Islam lebih dominan. Ia menjadikan teologirasional sebagai pembangun konsep-konsep metodologinya dan menjadikan filsafat sebagai media pendorong berpikir kritis sekaligus media penghubung kesenjangan hasil pemikirannya dari ketentuan teks-teks hukum (Alquran dan sunah) visi filosofisnya, esensi legalisasi Alquran terletak pada ajaran dasar dan prinsip-prinsip umum yang merupakan tujuan dan nilai-nilai moral-sosial Alquran; (2) sebagai mujtahid kontemporer, Rahman berusaha membangun formalisme "hadis dan ijmak"' sebagai dasar hukum Islam melalui pendekatan kritis-historis, lalu menggantikannya dengan konsep "sunah": sunah nabi dan sunah yang hidup. Sunah nabi sebagai konsep "pemayung" yang bersifat luas dan tidak bermuatan sempit, sedangkan "sunah yang hidup" merupakan ijmak dan konsensus suatu masyarakat yang merupakan produk interaksi ijtihad-ijtihad pribadi. Rahman bersikeras membangun kembali hubungan harmonis antara "sunahijtihad-ijmak" yang telah dikacaubalaukan dalam pemikiran hukum klasik; (3) melalui dua gerakan dan serangkaian langkah metodis yang disistematisir melalui tiga pendekatan: historis, kontekstual, dan sosiologis. Gerakan pertama lebih dikhususkan terhadap ayat-ayat hukum. Ide pokoknya adalah penerapan metode berpkir "induktif": berpikir dari ayat-ayat spesifik menuju kepada prinsip, atau berpikir dari aturan-aturan legal spesifik menuju kepada moral-sosial yang bersifat umum yang terkandung di dalamnya. Gerakan kedua merupakan upaya perumusan prinsip-prinsip umum, nilai-nilai dan tujuan-tujuan Alquran yang telah disistematisasikan lewat gerakan pertama. Pada dasarnya rumusan kedua ini tidak berbeda dengan metode "tahqîq al-manât $\square$ " yang juga dianut oleh Al-Amidi, yaitu 
metode untuk mengetahui sekaligus memastikan adanya ilat huukm pada kasus (waqi'at) yang akan ditetapkan hukum atasnya. Dari keseluruhan konsep metodologi Rahman, dapat disimpulkan bahwa "tidak ada otoritas hukum yang bersifat mutlak dan abadi, melainkan prinsip-prinsip moral-sosial Islam", tidak teks Alquran, tidak hadis, tidak pula ijmak. Ketiganya itu mengandung unsur-unsur situasional dan kondisional tertentu; (4) metode ijtihad Rahman yang dikembangkan sebagai metodologi pembaruan hukum Islam bukanlah merupakan sesuatu yang baru, melainkan suatu kelanjutan dari suatu proses kesinambungan pemikiran hukum Islam yang cukup berharga. Akan tetapi, Rahman menolak ijtihad sebagai hak privilese exlusive kalangan ulama, karena menurutnya, keterlibatan para saintifik lainnya amat diperlukan dalam upaya mengaktualisasikan hukum Islam baik dalam tataran konseptual maupun dalam tataran operasional untuk suatu solusi atau alternatif hukum bagi kemanusiaan; dan (5) sebagai konsekuensi logis dari konsep metodologi Rahman, terlihat dalam aplikasi hukum yang diinginkannya, meskipun pada akhirnya menuai reaksi pro-kontra karena dinilai sangat kontroversial. Dengan gagasan dan pemikiran yang dikemukakannya berkaitan dengan masalah zakat, bunga bank, poligami, keluarga berencana dan penyembelihan hewan dengan mekanis seperti yang telah dicontohkan, kesemuanya menunjukkan identitas Rahman sebagai pemikir neo-modernis yang belum seluruh kalangan umat bersedia dan mampu menerimanya, terutama kalangan ulama tradisional yang menganut faham "Ahl al-Sunah wa alJamâ'ah" yang pemikiran hukumnya terlalu berorientasi pada fikih klasik.

Dengan memahami metode ijtihad Fazlur Rahman yang digagas dalam suatu kemasan metodologi yang berorientasi progresif kontekstual, tanpa bermaksud mengurangi penghargaan terhadap pemikiran ulama klasik, agaknya merupakan sikap dan langkah yang perlu disinambungkan dalam upaya pengkajian hukum Islam meresponi perkembangan era globalisasi. Konsistensi Rahman dalam melakukan ijtihad dengan membatasinya pada masalah muamalah dan menghindari untuk memasuki wilayah ibadah dan akidah kiranya merupakan langkah "kearifan" yang dimilikinya yang patut diteladani 
oleh para "mujtahid pemula"-kalau tidak mau disebut mujtahid serampangan- seperti banyak bermunculan akhir-akhir ini di Indonesia yang sangat "menggamangkan".

Betapapun, perubahan dan pembaruan dalam kehidupan ini merupakan suatu keniscayaan, tetapi tidak berarti menjungkirbalikkan nilai-nilai asasi ajaran Islam, hanya untuk suatu kepentingan "popularitas" ataukah tanpa disadari ada kepentingan politik yang terselubung yang melatarbelakanginya.

\section{DAFTAR PUSTAKA}

Abû Zahra. t.th. Usûl al- Fiqh. Bairut: Dâr al-Fikr.

Amal, Taufiq Adnan. 1989. Islam dan Tantangan Modernitas. Bandung: Mizan.

.1993. "Fazlur Rahman dan Usaha-Usaha Neo-Modernisme Islam Dewasa ini" dalam Fazlur Rahman, Metode dan Alternatif: Neomodernisme Islam Fazlur Rahman (Terj.). Cet. ke-5. Mizan: Bandung.

al-Amîdî, Sayf al-Dîn Abû Hasan 'Alî ibn Abî 'Alî. t.th. Al-Ihkâm fĩ Us $\square \hat{u} l$ al-Ahkâm. Kairo: Muassasat al-Nahdah.

Anderson. 1956. Islamic Law in the Muslim World. New York: New York University Press.

Departemen Pendidikan dan Kebudayaan RI. 1988. Kamus Besar Bahasa Indonesia. Jakarta: Balai Pustaka.

Esposito, John L. 1982. Women in Muslim Family Law. Syracouse:: Syracouse University Press.

Iqbal, Muhammad. 1983. Reconstruction of Religious Thought in Islam (Terj.). Jakarta: Bulan Bintang.

Mas'udi, A. Ghufron. 1997. Pemikiran Fazlur Rahman tentang Metodologi Pembaharuan Hukum Islam. Cet. ke-1. Jakarta: Raja Grafindo Persada.

Nasution, Harun. 1992. Pembaruan dalam Islam. Jakarta: Bulan Bintang.

Rahman, Fazlur. 1987. Islam Modern Tantangan Pembaruan Islam Terjemahan oleh Rusdi Karim \& Hamid Basyaib. Cet. ke-1. Yokyakarta: Salahuddin Press.

.1957. "Implementation of the Islamic Concept of State in the Pakistan Milleu", Islamic Studies. Vol. 6. 
Jurnal Hunafa, Vol. 6, No.1, April 2009: 29-52

.1965. Islamic Methodology in History. Karachi: Central of Islamic Research Institution.

1976. "Same Islamic Issues in Ayyub Khan Era", Essay on Islamic Civilization, Mac Donald (Ed.). Leiden: B.J. Brill. .1979. "Toward Reformulating the Methodology of Islamic Law", International and Politic Vol. 12.

.1980. Islam and Modernity. Transformation of Intellectual Tradition. Chicago: Chicago University Press. .1997.Islam. Chicago: Chicago University Press. 